\title{
The Design of Teacher Salary Computerization System
}

\author{
Endang Purwanti, Phong Thanh Nguyen, A. Dinesh Kumar, R. Pandi Selvam, K. Shankar
}

\begin{abstract}
The rapid development of computer technology has an important role in supporting the development process in current communication era. However, the development of this technology cannot be used optimally at Gajah Mada Vocational High School (Bahasa: Sekolah Menengah Kejuruan (SMK)). In Gajah Mada Pati Vocational School, the processing of salary data has not used a computerized system, so it took a long time to process salary data and the possibility of error and data duplication. From these problems, it is necessary to design a computerized system using system design tools in form of ERD, DFD, as well as the design of input and output. Then the researcher tried to help provide an opinion for the salary data processing information system in order reducing the occurrence of error and speeding up the salary calculation process. From the paper done by the researcher, it is hoped that this new system can be used as well as possible. In this new system, the media is provided to hold the data base and media is provided to enter data, to change data, to delete data and to print report.
\end{abstract}

Keywords : Application, Salary, Gajah Mada vocational high school.

\section{INTRODUCTION}

\subsection{Background}

Gajah Mada 01 Vocational High School located at street Pasar Bulumanis, Margoyoso, Pati use of the old system that has not been computerized, and this is caused obstacles to get accurate information. This is caused by the process of collecting and processing data still done manually. The author encounters a problem where the teacher salary process was still manual and frequent error in calculating the salary of teacher. Salary calculation based on various different details inhibited the treasurer's performance process. Errors in calculating salaries can be fatal because it will affect the preparation of financial report. Therefore, it is necessary to have a Teacher Salary Information System in order school staff are no longer wrong in collecting data on teacher salary and financial total. To overcome all these problems, the

Revised Manuscript Received on July 22, 2019.

* Correspondence Author

Endang Purwanti, Department of Information Systems, STMIK Pringsewu, Lampung, Indonesia.

Phong Thanh Nguyen*, Department of Project Management, Ho Chi Minh City Open University, Vietnam. E-mail: phong.nt@ou.edu.vn

A. Dinesh Kumar, Research Scholar, Department of Computer Applications, Alagappa University, Karaikudi, India. E-mail: dineshasoka661@gmail.com

R. Pandi Selvam, Assistant Professor and Head, PG Department of Computer Science, Ananda College, Devakottai, India. E-mail: pandiselvamraman@gmail.com

K. Shankar, Department of Computer Applications, Alagappa University, Karaikudi, India. E-mail: shankarcrypto@gmail.com treasurer needs a system that will make it easier to complete the work.

\subsection{Research Problem}

The teacher salary process at the Gajah Mada 01 Vocational High School Margoyoso, Pati was still manual and there were often error in calculating the salary of teachers or staff employees.

\subsection{Limitation of the Research}

Based on the description above, the researcher limit the problems that exist in this study as follows:

a. The study was only conducted at the Gajah Mada 01 Vocational High School (SMK), Margoyoso Pati.

b. The information system will be created by using a visual basic programming language.

c. Analysis and design of this assessment application system does not discuss the further computer security system and network contained on this application.

\subsection{Research Objective}

Producing a new information system for the finance department about employee salary at Gajah Mada 01 Vocational High School, Margoyoso, Pati.

\subsection{Benefit of the Research}

To simplify the process of employee and staff tabulation salary data at the Gajah Mada 01 Vocational High School, Margoyoso, Pati.

\section{LITERATURE REVIEW}

\subsection{The Definition of System}

The system is a group of elements that are integrated with the intention of the same person to achieve a goal [1].

The system can be defined as a unit consisting of two or more components or sub-systems that interact to achieve a goal [2]. From some definitions of the system mentioned above, the researcher concludes that the system is a collection of interrelated or integrated elements created to achieve a common goal [3]

\subsection{The Definition of Computerization}

Computerization is the development of a system that is not originally using a computer into a system that using computer [4]. Computerization is the use of computer as a tool to complete task in completing work manually [5]. The activity of computerization is data processing in producing important information for

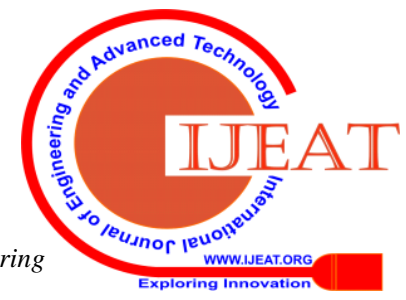




\section{The Design of Teacher Salary Computerization System}

management, so the person concerned is able to better control the company for which he or she is responsible [6].

\subsection{The Definition of Salary}

Salary is generally defined as payments for the delivery of service paid to employees who have managerial level and generally the payment for the delivery of service performed by employees (the production part) and are paid based on working days, working hours, or the number of product units that have been produced by employees [7]. In the implementation of the salary system in each company is not always the same, it depends on the condition of the company [8].

\subsection{The Definition of Information}

Information is the result of processing data obtained from each element of the system into an easily understood form and is a relevant knowledge needed by people to increase their understanding of the facts that exist [9].

Information is the result of processing data (facts) into something meaningful and valuable for decision making [10]. Information cannot be separated from aspects of human life [11]. Who, when, and wherever someone will need information [12].

Information is a series of data that has a temporary nature, depending on time, able to give a surprise to those who receive it [13]. Information that have no value, usually because the data set is incomplete or out of date [14].

\section{RESEARCH METHODOLOGY}

\subsection{Data Processing}

The research methods used were as follows:

1. Observation Method, through this method the writer made direct observation at Gajah Mada Vocational High School, observation is made to see directly to the work process [15].

2. Interview Method, to find out the complex problems faced as well as the ongoing salary process at the Gajah Mada Vocational High School [16].

\subsection{Data Analysis}

While this research design used the waterfall method below:

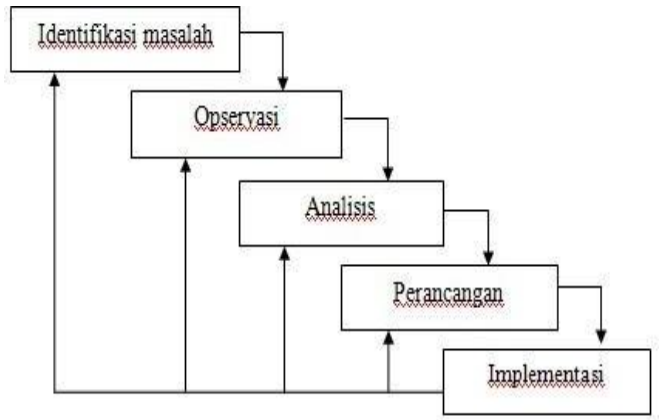

Figure 1: Waterfall Method

1 Research Identification
The problem identification of this research used interview method which aimed to find and collect data [15] by asking questions to the interviewees [17].

\section{Observation}

Observation is looking for data by survey of promotional method [18], marketing that has been done by the marketing team [19].

\section{Analysis}

Analysis analyzes the problems found in the field when the offline marketing process happened in the field [20].

4 Design

Design is a method by designing for the purpose of delivering information relating to the website created [21].

\section{Implementation}

Implement the results of making products with online way [22] with hosting and domain facilities so the wider community can get information quickly [23].

\section{DESIGN AND IMPLEMENTATION}

\subsection{Design}

- Context Diagram

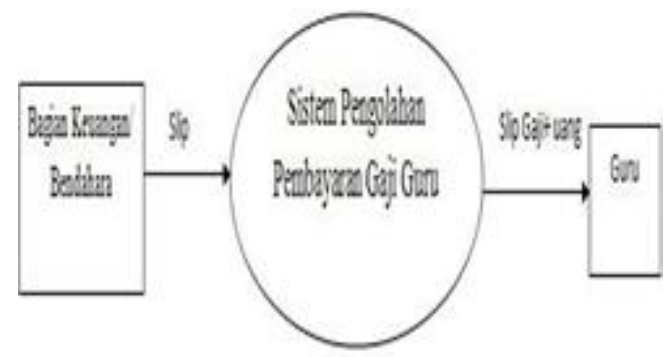

Figure 2: Context Diagram

\section{- O Level Diagram}

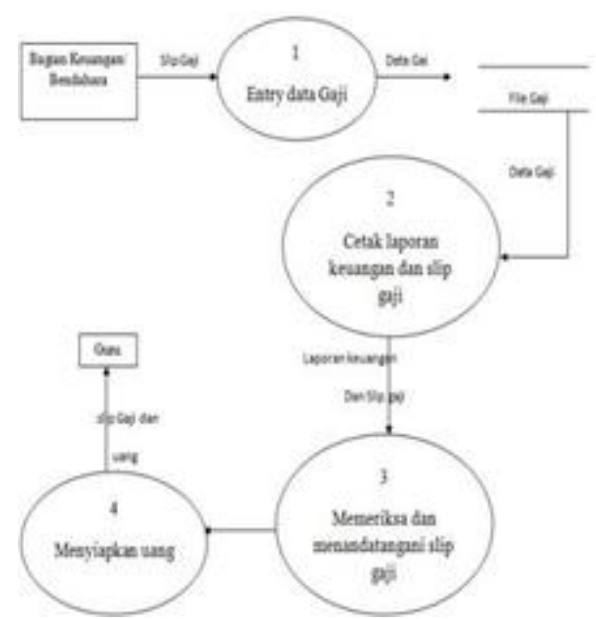

Figure 3: O Level Diagram 
- ERD

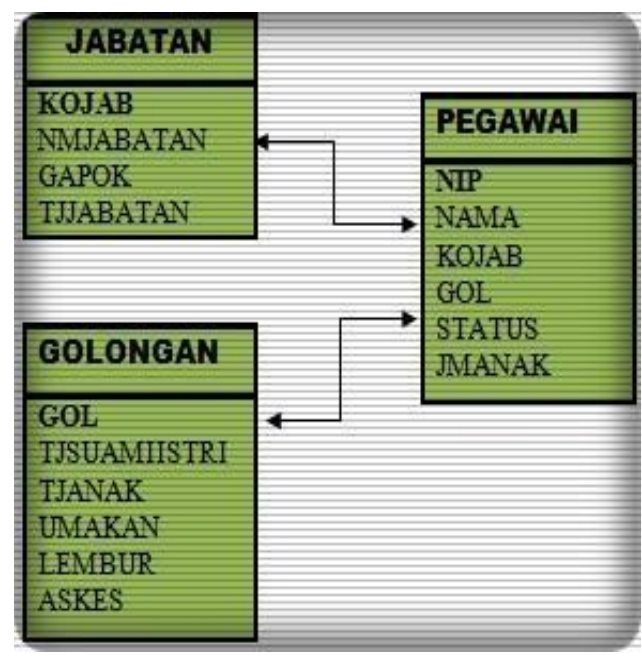

Figure 4: ERD Diagram

\subsection{Implementation}

4.2.1 The design of the login menu

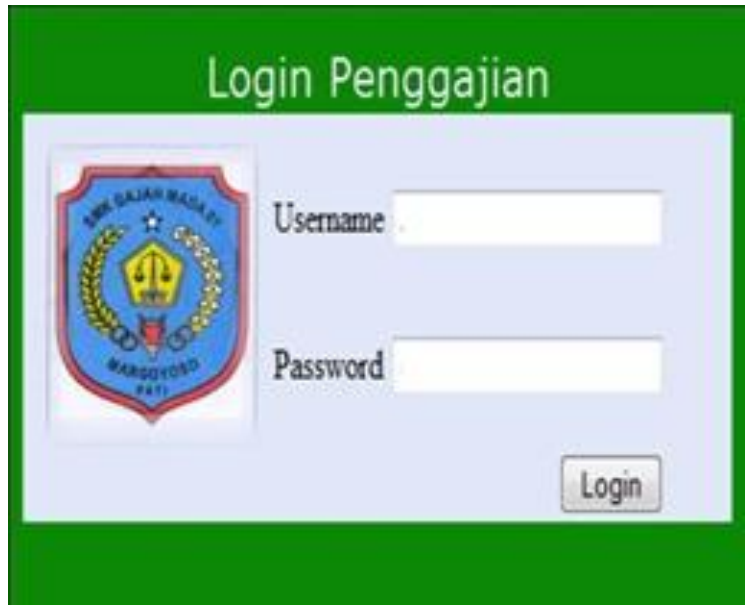

Figure 5: Login Menu

\section{Teacher Data Input Design}

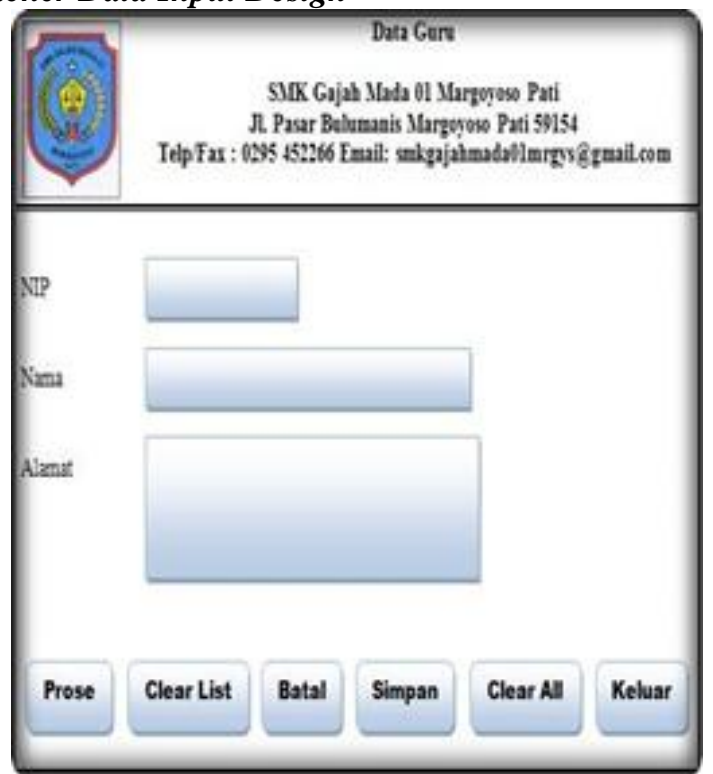

Figure 6: Teacher Data

\section{Teacher salary input data plan}

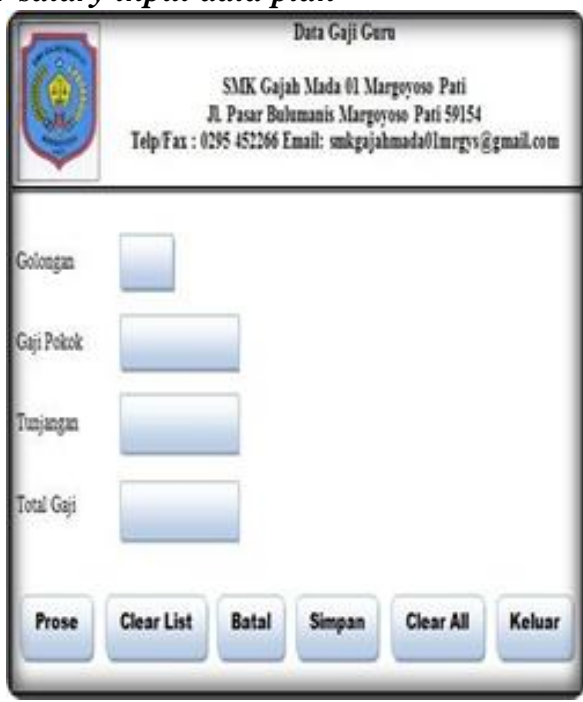

Figure 7: Teacher Salary Data

\section{Salary Data Processing Input Design}

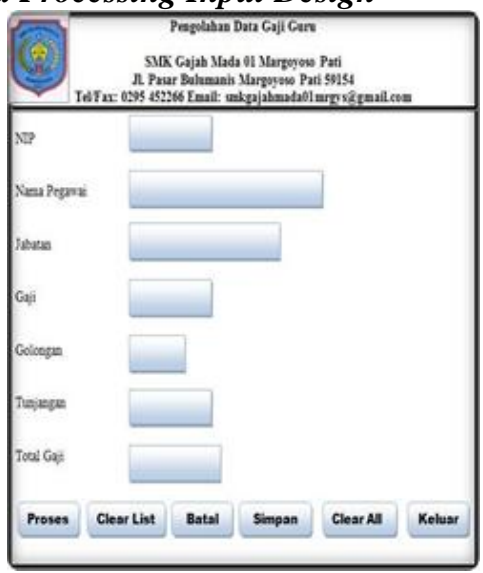

Figure 8: Teacher Salary data processing

The design of monthly salary report output

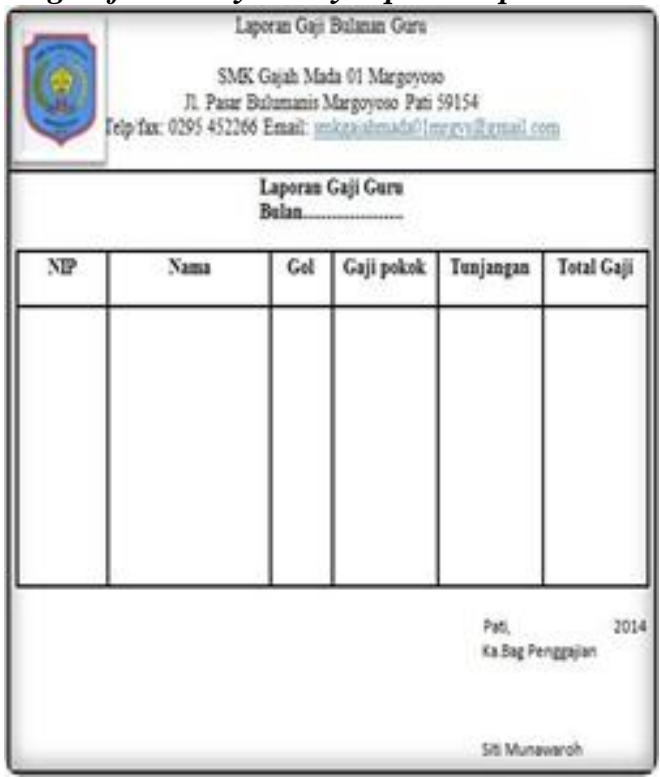

Figure 9: Monthly Salary Report

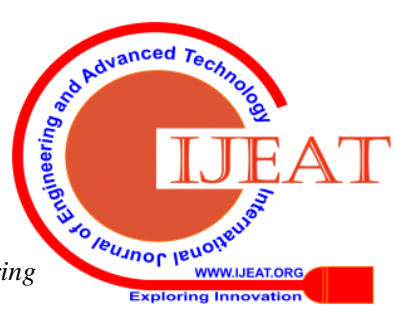




\section{The Design of Teacher Salary Computerization System}

\section{CONCLUSION AND SUGGESTIONS}

\subsection{Conclusion}

After the researcher conducted a research on Computerized Data Processing System of Teacher Salary at the Gajah Mada Vocational High School, the conclusions can be drawn as follows:

1) With the new information system, it could help school treasurer, especially during the salary processing as to produce report or presentation of information more quickly and accurately.

2) It could be reduce data storage because the data were already stored in a computerized system, only manual data is needed during the power failure or broken computer.

3) To overcome some of the problems that might often occur, we need a development system from the use of the existing computer.

\subsection{Suggestions}

In researching the computerized system of processing teacher salary at the Gajah Mada Vocational School, the researcher gave the following suggestions:

1) It was better to immediately replace the existing information system that was still being done, with a new information system.

2) The use of computer technology on the new system is needed in handling Teacher Salary Data processing so it could be provide the right, Fast and Accurate qualities.

3) Computerized salary data processing system proposed in this report can be used by Gajah Mada Vocational High School as a reference in developing a new system, which could cover the weaknesses of the old system.

\section{REFERENCES}

1. Chienwattanasook, K., Wattanapongphasuk, W., Prianto, A., \& Jermsittiparsert, K. 2019. "Corporate Entrepreneurship and Business Performance of Logistic Companies in Indonesia." Industrial Engineering \& Management Systems 18 (3): 538-547.

2. Dawabsheh, M., Hussein, A., \& Jermsittiparsert, K. 2019. "The Triangular Relationship between TQM, Organizational Excellence and Organizational Performance: A Case of Arab American University Palestine.” Management Science Letters 9 (6): 921-932.

3. Jermsittiparsert, K., Siam, M., Issa, M., Ahmed, U., \& Pahi, M. 2019. "Do Consumers Expect Companies to Be Socially Responsible? The Impact of Corporate Social Responsibility on Buying Behavior.' Uncertain Supply Chain Management 7 (4): 741-752.

4. Syazali, M., Putra, F., Rinaldi, A., Utami, L., Widayanti, Umam, R., \& Jermsittiparsert, K. 2019. "Partial Correlation Analysis Using Multiple Linear Regression: Impact on Business Environment of Digital Marketing Interest in the Era of Industrial Revolution 4.0." Management Science Letters 9 (11): 1875-1886.

5. Sae-Lim, P. \& Jermsittiparsert, K. 2019. "Is the Fourth Industrial Revolution a Panacea? Risks toward the Fourth Industrial Revolution: Evidence in the Thai Economy." International Journal of Innovation, Creativity and Change 5 (2): 732-752.

6. Chatchawanchanchanakij, P., Arpornpisal, C., \& Jermsittiparsert, K. 2019. "The Role of Corporate Governance in Creating a Capable Supply Chain: A Case of Indonesian Tin Industry." International Journal of Supply Chain Management 8 (3): 854-864.

7. Hartinah, S., Suharso, P., Umam, R., Syazali, M., Lestari, B., Roslina, R., \& Jermsittiparsert, K. 2020. "Teacher's Performance Management: The Role of Principal's Leadership, Work Environment and Motivation in Tegal City, Indonesia." Management Science Letters 10 (1): 235-246.
8. Haseeb, M., Hussain, H., Slusarczyk, B., \& Jermsittiparsert, K. 2019. "Industry 4.0: A Solution towards Technology Challenges of Sustainable Business Performance.” Social Sciences 8 (5): 184.

9. Haseeb, M., Hussain, H., Kot, S., Androniceanu, A., \& Jermsittiparsert, K. 2019. "Role of Social and Technological Challenges in Achieving a Sustainable Competitive Advantage and Sustainable Business Performance.” Sustainability 11 (14): 3811.

10. Haseeb, M., Kot, S., Hussain, H., \& Jermsittiparsert, K. 2019. "Impact of Economic Growth, Environmental Pollution, and Energy Consumption on Health Expenditure and $\mathrm{R}$ and $\mathrm{D}$ Expenditure of ASEAN Countries." Energies 12 (19): 3598.

11. Huda, S., Tsani, I., Syazali, M., Umam, R., \& Jermsittiparsert, K. 2020 "The Management of Educational System Using Three Law Auguste Comte: A Case of Islamic Schools.” Management Science Letters 10 (3) (In press), DOI: 10.5267/j.msl.2019.9.018.

12. Usak, M., Kubiatko, M., Shabbir, M., Dudnik, O., Jermsittiparsert, K., \& Rajabion, L. 2019. "Health Care Service Delivery Based on the Internet of Things: A Systematic and Comprehensive Study." International Journal of Communication Systems 32 (14): e4179.

13. Jermsittiparsert, K., Ambarita, D., Mihardjo, L., \& Ghani, E. 2019. "Risk-Return through Financial Ratios as Determinants of Stock Price: A Study from ASEAN Region." Journal of Security and Sustainability Issues 9 (1): 199-210.

14. Thabhiranrak, T. \& Jermsittiparsert, K. 2019. "Towards Sustainable Functioning of Organization: Women Empowernment and Corporate Management Culture.” Journal of Security and Sustainability Issues 9 (1): 321-332

15. Maseleno, A., Hardaker, G., Sabani, N., \& Suhaili, N. (2016). Data on multicultural education and diagnostic information profiling: Culture, learning styles and creativity. Data in brief, 9, 1048.

16. Maseleno, A., Huda, M., Jasmi, K. A., Basiron, B., Mustari, I., Don, A G., \& bin Ahmad, R. (2019). Hau-Kashyap approach for student's level of expertise. Egyptian Informatics Journal, 20(1), 27-32.

17. Maseleno, A., Huda, M., Siregar, M., Ahmad, R., Hehsan, A., Haron, Z., ... \& Jasmi, K. A. (2017). Combining the previous measure of evidence to educational entrance examination. Journal of Artificial Intelligence, 10(3), 85-90.

18. Chienwattanasook, K. \& Jermsittiparsert, K. 2019. "Impact of Entrepreneur Education on Entrepreneurial Self-Employment: A Case Study from Thailand.” Polish Journal of Management Studies 19 (1): 106-116

19. Jermsittiparsert, K., Sutduean, J., Sriyakul, T., \& Khumboon, R. 2019. "The Role of Customer Responsiveness in Improving the External Performance of an Agile Supply Chain.” Polish Journal of Management Studies 19 (2): 206-217.

20. Jermsittiparsert, K., Sutduean, J., \& Sriyakul, T. 2019. "Effect of Service Innovation and Market Intelligence on Supply Chain Performance in Indonesian Fishing Industry." Industrial Engineering \& Management Systems 18 (3): 408-417.

21. Jermsittiparsert, K., Namdej, P., \& Somjai, S. 2019. “Green Supply Chain Practices and Sustainable Performance: Moderating Role of Total Quality Management Practices in Electronic Industry of Thailand.' International Journal of Supply Chain Management 8 (3): 33-46.

22. Somjai, S. \& Jermsittiparsert, K. 2019. "The Trade-off between Cos and Environmental Performance in the Presence of Sustainable Supply Chain." International Journal of Supply Chain Management 8 (4): 237-247

23. Jermsittiparsert, K. \& Sawasdee, A. 2012. "Formal Education for Non-Thai or Undocumented Person in Thailand amidst the Challenge of Nationalism and Transnationalism: A Case Study of Wat Sirimongkhol School, Samut Sakhon Province.” Kasetsart Journal - Social Sciences 33 (2): 203-213. 